\title{
Muvi schmallenbergi gen. nov., sp. nov. (Crustacea, Tanaidacea) from the southeast Australian coast, with comments on the distribution and habitat preferences of Chondropodinae
}

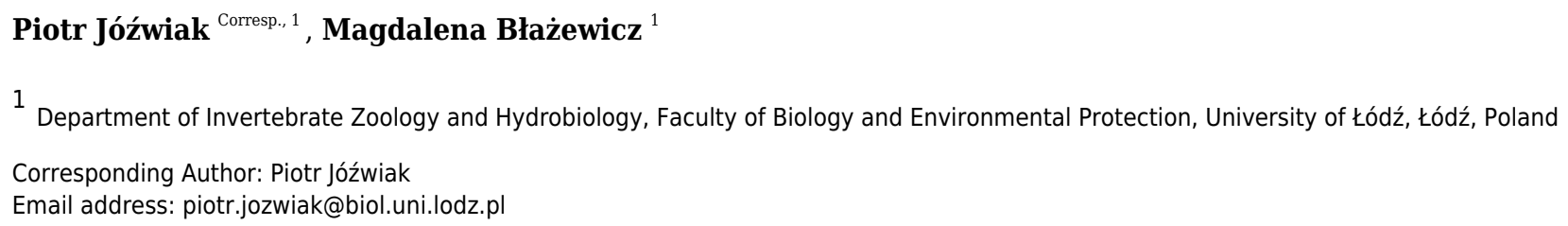

Based on material collected from the shelf off southeast Australia (offshore of Portland), a new genus and new species, Muvi schmallenbergi gen. nov., sp. nov., of the tanaidacean family Metapseudidae, is described. Muvi is distinguishable from other genera within the subfamily Chondropodinae by having equally long antennular flagella. It also differs from other Chondropodinae by a combination of characters such as eyelobes with a group of visual elements, rostrum with smooth lateral edges, pereonites with lateral processes and pleotelson lacking lateral process, antennule article-1 with a single apophysis, maxillule inner lobe well-developed, labial palp bearing three distal setae, cheliped exopod welldeveloped and setose, pereopod-1 coxa with distinct apophysis, pleopods in five pairs, and uropod basis without apophysis. The genus Deidamiapseudes Sganga \& Roccatagliata, 2016 is moved from Chondropodinae (Metapseudidae) to Apseudoidea incertae sedis. An identification key for the genera within Chondropodinae is given, and their distribution is discussed. 
1 Muvi schmallenbergi gen. nov., sp. nov. (Crustacea, Tanaidacea) from the southeast

2 Australian coast, with comments on the distribution and habitat preferences of

3 Chondropodinae

4

5 Piotr Jóźwiak, Magdalena Błażewicz

6 Department of Invertebrate Zoology and Hydrobiology, Faculty of Biology and Environmental

7 Protection, University of Łódź, Banacha 12/16, Łódź 90-237, Poland

8 Corresponding author: Piotr Jóźwiak, email: piotr.jozwiak@biol.uni.lodz.pl

9

10

11

12

13

14

15

16

17

18

19

20

21

22

23

Peer] reviewing PDF | (2020:02:45854:3:0:NEW 14 May 2021) 


\section{Abstract}

Based on material collected from the shelf off southeast Australia (offshore of Portland), a new genus and new species, Muvi schmallenbergi gen. nov., sp. nov., of the tanaidacean family Metapseudidae, is described. Muvi is distinguishable from other genera within the subfamily Chondropodinae by having equally long antennular flagella. It also differs from other

32 Chondropodinae by a combination of characters such as eyelobes with a group of visual elements, rostrum with smooth lateral edges, pereonites with lateral processes and pleotelson lacking lateral process, antennule article-1 with a single apophysis, maxillule inner lobe welldeveloped, labial palp bearing three distal setae, cheliped exopod well-developed and setose, pereopod-1 coxa with distinct apophysis, pleopods in five pairs, and uropod basis without apophysis. The genus Deidamiapseudes Sganga \& Roccatagliata, 2016 is moved from Chondropodinae (Metapseudidae) to Apseudoidea incertae sedis.

An identification key for the genera within Chondropodinae is given, and their distribution is discussed.

\section{Introduction}

43 Tanaidacea, small benthic peracarid crustaceans, represent a poorly recognized component of 44 marine ecosystems. Until the end of millennium, the Australian Tanaidacea were known only 45 from few taxonomic publications (Haswell, 1882a, b; Haswell, 1885; Whitelegge, 1901; Boesch, 46 1973; Băcescu, 1981; Sieg, 1993; Edgar, 1997). The turning point was the publication of the 
47 results from several surveys dedicated to the tanaidacean fauna on the Australian shelf. For

48

49 example, Bamber (2005) described 24 new species from Esperance Bay, Guţu (2006a) reported 13 new species from tropical zones of Australia, Edgar (2008) reported 12 new species of the family Tanaididae in Tasmanian waters, and Błażewicz-Paszkowycz \& Bamber (2012) described 42 new species from the Bass Strait. As a result, the number of the tanaidaceans known to occur along the Australian coast increased from 22 to 209 (as summarized by Bamber, 2008; Edgar, 2008; Błażewicz-Paszkowycz \& Bamber, 2009; Błażewicz-Paszkowycz \& Zemko, 2009; Stępień \& Błażewicz-Paszkowycz, 2009a, b; Błażewicz-Paszkowycz \& Bamber, 2012; Edgar, 2012; Jóźwiak \& Jakiel, 2012; Bamber, 2013; Bamber \& Błażewicz-Paszkowycz, 2013; Stepień \& Błażewicz-Paszkowycz, 2013; Gellert \& Błażewicz, 2018). This demonstrates the high diversity of these small and poorly recognized peracarids along the Australian coast (Bamber \& Błażewicz-Paszkowycz, 2013), with a high level of endemism (Błażewicz-Paszkowycz \& Bamber, 2012; Błażewicz-Paszkowycz, Bamber \& Anderson, 2012). However, the total number of Tanaidacea living in the Australian waters is still unknown (Stępień, Pabis \& Błażewicz, 2018). Based on studies on the West Australian coast, Poore et al. (2015) reported almost 200 tanaidacean species, pointing them out as the most abundant taxon in terms of both individuals and species. This number, although double the previously known number of species from Australian waters, probably represents only a fraction of the tanaidacean fauna.

The metapseudid subfamily Chondropodinae is currently represented by 29 species classified to nine genera (WoRMS, 2019) distributed in tropical to temperate waters, e.g., the Adriatic Sea, along the Brazilian coast, the Gulf of Guinea, Mauritania, the Gulf of Mexico, the Caribbean Sea, and the Coast of Malaysia (Guţu, 1984; Guţu, 1996; Guţu, 2002; Bamber \& Sheader, 2005; Guţu, 2006a; Guţu, 2014; Jakiel et al., 2015). Two species of Australian Chondropodinae are 
70

71

72

73

74

75

76

77

currently known: Julmarichardia gutui Ritger \& Heard, 2007, found along the Northwest Australian coast (Ritger \& Heard, 2007), and Bamberus jinigudirus Stępień \& BłażewiczPaszkowycz, 2013, collected from Ningaloo coral reefs (Stępień \& Btażewicz-Paszkowycz, 2013). Described herein, Muvi schmallenbergi sp. nov. is the third Chondropodinae species recorded from Australia.

Materials and methods

The analyzed sample was taken during the SLOPE campaign off Portland, Victoria, Australia at the depth of $49.5 \mathrm{~m}$, using a Smith-McIntyre grab. The sample was preserved in formaldehyde, identified, and fixed in 70\% ethanol. Images of body habitus were taken with a Leica M125 stereomicroscope combined with a DFC295 camera and the LAS V4.5 software. Appendages were dissected in a glycerin solution using chemically sharpened tungsten needles, mounted in glycerin on slides, and sealed with nail varnish. Drawings were made using a Nikon Eclipse 50i microscope combined with a camera lucida, redrawn with China ink, and finally edited and cleared with Corel PHOTO-PAINT X7. The body length-to-width ratio was calculated using measurements from the tip of the carapace to the end of the pleotelson and of the widest part of the carapace; the length and width of the articles were measured along their central axes. The general morphological terminology followed that proposed by Błażewicz-Paszkowycz, Bamber \& Jóźwiak (2013). To simplify species descriptions, the expression ' $N \mathrm{x}$ ' replaces ' $N$ times as long as' and ' $N$ L:W' replaces ' $N$ times longer than wide'. The type material was deposited in the Melbourne Museum (NMV, Australia). Distribution maps were generated using the freeware QGIS. 
92 The electronic version of this article in Portable Document Format (PDF) will represent a 93 published work according to the International Commission on Zoological Nomenclature (ICZN), 94 and hence the new names contained in the electronic version are effectively published under that 95 Code from the electronic edition alone. This published work and the nomenclatural acts it 96 contains have been registered in ZooBank, the online registration system for the ICZN. The 97 ZooBank LSIDs (Life Science Identifiers) can be resolved and the associated information viewed 98 through any standard web browser by appending the LSID to the prefix http://zoobank.org/. The 99 LSID for this publication is: urn:lsid:zoobank.org:pub:E516068D-B9FC-4267-BC3C$1006 \mathrm{C} 97 \mathrm{CF} 6728 \mathrm{C} 1$. The online version of this work is archived and available from the following 101 digital repositories: PeerJ, PubMed Central and CLOCKSS.

\section{Results}

104 Systematics

105 Order Tanaidacea Dana, 1849

106 Suborder Apseudomorpha Sieg, 1980

107 Superfamily Apseudoidea Leach, 1814

108 Family Metapseudidae Lang, 1970

109 Subfamily Chondropodinae Guţu, 2008

110 Diagnosis (after Guţu, 2008). Body dorsoventrally flattened, with small lateral or anterolateral 111 acute or rounded processes at the level of pereonites. Pleon with five short pleonites (with or 112 without lateral plumose setae) and a short pleotelson (with a small acute lateral process in the 113 first half). Antennule peduncle usually with at least one conspicuous denticle on the inner margin 114 of the first article; at least outer flagellum long, multi-segmented. Antenna peduncle with second 
115 article long, in rare cases without spiniform denticles on the inner margin; squama present

116 (small). Mandible with tri-articled palp. Maxillule with bi-articled palp. Maxilliped with third

117 article of the palp evidently longer than broad, sometimes shorter than the second one; second

118 article of the palp with a great outerodistal spine and exceptionally with numerous plumose setae

119 on the outer side. Cheliped obvious dimorphic or not, with exopod. Pereopod-1 well-developed,

120 much larger than the following pereopods, with exopod; basis thick with long plumose setae

121 which alternate with spiniform denticles on the dorsal margin (in rare cases, denticles absent);

122 sometimes coxa with a spiniform prolongation (more or less developed). Pereopods 2-6 thin,

123 different from pereopod-1; pereopods 2, 3 and 5 with long and similar propodus (much longer

124 than the carpus, the last of about the same length with the merus), slightly curved, with at most

125 four sternal spines; dactylus also thin and long, with a well-developed claw. Pleopods present,

126 biramous, in three or five pairs. Uropod with multi-segmented (but not long) rami.

127 Genera included: Bamberus Stępień \& Błażewicz-Paszkowycz, 2013; Calozodion Gardiner, 128 1973; Chondropodus Guţu, 2006; Hoplopolemius Sganga \& Roccatagliata, 2016; 129 Julmarichardia Guţu, 1989; Trichapseudes Barnard, 1920; Vestigiramus Guţu, 2009; Zaraza 130 Guţu, 2006.

\section{Remarks}

132 Chondropodinae is considered a monophyletic taxon with precise and consistent diagnosis 133 among the included genera (Guţu, 2008, 2009; Stępień \& Błażewicz-Paszkowycz, 2013); it has 134 been suggested as a separate family (Stepień and Błażewicz-Paszkowycz, 2013). The definition of 135 Chondropodinae by Guţu (2008, 2009), supplemented by Stępień and Błażewicz-Paszkowycz 136 (2013), is based on the setation of the pereopod-1 basis (row of plumose setae on dorsal margin), 
137 the relative carpus-to-merus length of pereopods 2, 3, and 5, and the length of the propodus,

138 which appears clearly longer than the carpus and has at least four sternal spines.

139 This coherent definition of the subfamily was disrupted after the classification of the genus

140 Deidamiapseudes Sganga \& Roccatagliata, 2016 within Chondropodinae (classification provided

141 by WoRMS, 2019). In contrast to the other Chondropodinae, the genus Deidamiapseudes lacks

142 plumose setae on the pereopod-1 basis, whereas the propodus of pereopods 2, 3, and 5 is shorter

143 than the carpus; pereopods 2-3 propodus has seven to eight ventral spines.

144 Intriguingly, Sganga and Roccatagliata (2016) decided to neither classify their genus to any

145 subfamily nor even to the apseudoidean family and noted that Deidamiapseudes shows some

146 morphological similarities to both Apseudidae and Metapseudidae, such as an apophysis on the

147 coxa of pereopod-1, recorded in both families, large spines on the inner margin of the antennule

148 peduncle article-1 found in Metapseudidae, but pereopods "adapted for walking", which is

149 characteristic for Apseudidae but not for Metapesudidae. Because Deidamiapseudes is a 150 morphologically clearly distinct from other Chondropodinae, we removed this genus from the 151 subfamily and placed in Apseudoidea, with an uncertain family status (incertae sedis).

152

153

154

155

156

157

Genus Muvi gen. nov.

urn:1sid:zoobank.org:act:60F20E13-CC0C-4779-828F-50A561E1BB85

Diagnosis. Rostrum triangular pointed, lateral margin smooth. Eyelobes with visual elements. Pereonites wider than long. Antennule peduncle of four articles, article-1 with only a single apophysis on the outerodistal corner; flagella equal in length, each with twelve segments. Maxillule inner lobe well-developed. Labial palp with three distal setae. Exopod on cheliped and pereopod-1 well-developed, with nine and eleven plumose setae, respectively. Pereopod-1 coxa 
160 with distinct apophysis. Bases of pereopods 1-6 without apophyses. Pereopod-1 propodus 1.5

161 times as long as wide. Pleopods in five pairs. Uropod basal article without hyposphaenium;

162 endopod of seven segments, exopod of three segments.

163 Type species: Muvi schmallenbergi gen. nov., sp. nov. (by monotypy).

164 Etymology. The name is an acronym for the Museum of Victoria (Melbourne, Australia), where

165 the type species of the new genus is deposited.

166

167 Remarks

168 Muvi gen. nov. is classified to the subfamily Chondropodinae, based on a combination of the 169 following subfamily characters: pleon of five free pleonites, antennule peduncle article-1 with 170 apophysis, antenna peduncle article-2 elongated, mandibular palp of three articles and pereopod-

1711 basis with a row of plumose setae dorsally. A multi-segmented inner flagellum of antennule 172 with the same size and segment number as the outer flagellum is the main character 173 distinguishing the new genus from other Chondropodinae. Moreover, Muvi differs from the 174 following genera:

175 - Bamberus by pleotelson without lateral process, antennule article-1 with single 176 apophysis, well-developed inner lobe of maxillule, labial palp with three setae distally and uropod basal article without apophysis. In Bamberus, the pleotelson has a single process on the lateral sides, antennule article-1 lacks apophyses, the inner lobe of maxillule is reduced and bears only two distal setae, the labial palp has two setae, and the uropod basis has a distinct apophysis (Stęień \& Błażewicz-Paszkowycz, 2013);

- Calozodion by having three strong setae distally on labial palp; there is only one distal spine in Calozodion (Guţu, 2002); 
183 - Chondropodus by having eyelobes with visual elements, pereonites with lateral 184 processes, a pleotelson without a lateral process, a labium with three distal setae, 185 pereopod-1 coxa with distinct apophysis, propodus only $1.5 \mathrm{~L}: \mathrm{W}$, pleopod exopod with a 186 single article. In Chondropodus, the eyelobes lack visual elements, pereonites do not 187 have lateral processes, labial palp has a single distal spine, pereopod-1 lacks coxal 188 apophysis, and propodus is at least twice as long as wide; the pleopod exopod is bi$189 \quad$ articled (Guţu, 2006a);

190 - Hoplopolemius in antennule peduncle article-1 with only a single apophysis. Article-1 of 191 the antennule peduncle in Hoplopolemius has clearly more than one apophysis 192 (Richardson, 1902; Guţu, 2002; Larsen \& Shimomura, 2006);

193 - Julmarichardia by having a rostrum with smooth lateral edges and antennule peduncle 194 article-1 with a single apophysis. The lateral edges of the Julmarichardia rostrum are 195 distinctly serrated, and the antennule peduncle article-1 in members of this genus has 196 more than one apophysis (Barnard, 1914; Guţu, 1989a; Guţu, 1989b; Bamber \& 197 Sheader, 2005; Ritger \& Heard, 2007);

198 - Trichapseudes by having five pairs of pleopods; in Trichapseudes, only three pairs of $199 \quad$ pleopods are present (Barnard, 1920);

200 - Vestigiramus in a well-developed and setose cheliped exopod. Vestigiramus has a 201 reduced uni-articled and naked cheliped exopod (Guţu, 2009);

$202 \quad$ - Zaraza by three setae distally on the labial palp and five pairs of pleopods. Zaraza has a 203 labial palp with a single terminal seta (spine) and three pairs of pleopods (Guţu, 2006b). 
2061 - Rostrum with marginal denticles ... Julmarichardia Guţu, 1989

207 - Rostrum without marginal denticles ... 2

2082 - Pereopod-1 propodus cylindrical, much longer than thick or the length of the carpus...3

209 - Pereopod-1 propodus wide, not much longer than thick or the length of the carpus ... 4

210 3- Uropod peduncle with strong apophysis dorsally ... Bamberus Stępień \& Błażewicz, 2013

211 Uropod peduncle without strong apophysis dorsally ... Chondropodus Guţu, 2006

2124 - Antennule inner flagellum bi-segmented ... 5

213 - Antennule inner flagellum multi-segmented ... 6

2145 - Cheliped exopod tri-articled, with terminal setae ... Calozodion Gardiner, 1973

215 Cheliped exopod uni-articled, without terminal setae ... Vestigiramus Guţu, 2009

2166 - Antennule inner flagellum equal in length to outer flagellum ... Muvi gen. nov.

217 Antennule inner flagellum shorter than outer flagellum ... 7

2187 - Pereopod-1 exopod with last article round (and large), having more than 20 plumose marginal

219 setae ... Trichapseudes Barnard, 1920

220 - Pereopod-1 exopod with last article normal (elongated), having clearly less than 20 plumose

221 marginal setae ... 8

2229 - Five pairs of pleopods ... Hoplopolemius Sganga \& Roccatagliata, 2016

223 - Three pairs of pleopods ... Zaraza Guţu, 2006

224

225 Muvi schmallenbergi sp. nov.

226 urn:lsid:zoobank.org:act:14743564-C6F2-42CE-A181-CE30F5C5A2C2

227 (Figs 1-3) 
228 Material examined. Holotype female (MNV J74649), $4.5 \mathrm{~mm}$, SLOPE 99, Victoria, Off

229 Portland, $38^{\circ} 31^{\prime} 34^{\prime \prime} \mathrm{S}, 141^{\circ} 58^{\prime} 46^{\prime \prime} \mathrm{E}$, depth $49.6 \mathrm{~m}, 11$ May 1994, Smith-McIntyre grab, 230 coll. G.C.B. Poore. Paratype, female (MNV J74648), $5.9 \mathrm{~mm}$, the same locality, dissected on 231 slides.

232 Diagnosis. As for the genus.

233 Etymology. The new species is dedicated to Barbara Schmallenberg.

234 Description of female (body of holotype, appendages from paratype)

235 Body (Fig. 1A, B) $4.5 \mathrm{~mm}$ long. Cephalothorax 21\% of total body length; rostrum triangular and 236 pointed (Fig. 1A, 2C); eyelobes pointed with visual elements (Fig. 1A, B). Pereon 47\% of total 237 body length; pereonites length-width ratio $0.3,0.4,0.5,0.5,0.5$, and 0.3 ; pereonites $2-5$ with 238 dorsoproximal apophyses on lateral margin. Pleon $32 \%$ of total body length; pleonites equal in 239 length, about $0.2 \mathrm{~L}: \mathrm{W}$, with pointed lateral margins; pleotelson just longer than the last three 240 pleonites combined.

241 Antennule (Fig. 2A) peduncle article-1 2.1 L:W and 1.9x article-2, with four simple and two 242 penicillate setae on the inner margin and one simple, one plumose seta, and four penicillate setae 243 on the outer margin; single apophysis present in the outerodistal corner; article-2 $1.2 \mathrm{~L}: \mathrm{W}$ and 244 1.9x article-3, with five simple and two penicillate setae subdistally; article-3 as long as wide, 245 with two simple setae distally; common article short and naked; flagella subequal, each with 12 246 segments, setation as figured (no aesthetasc present).

247 Antenna (Fig. 2B) peduncle article-1 short and naked; peduncle article-2 1.7 L:W and 3x article248 3, with three minute distal and subdistal setae; squama narrow, 4.5 L:W, with simple subdistal seta and three distal setae; peduncle article-3 $0.8 \mathrm{~L}: \mathrm{W}$ and $0.7 \mathrm{x}$ article-4, with two long simple setae distally; article-4 1.2 L:W and 0.9x article-5, with three penicillate distal setae; article-5 1.4 
251 L:W, with two short simple, two long simple, and two penicillate setae distally, and one mid-

252 length simple seta; flagellum of six segments, setation as figured.

253 Mouthparts. Labrum (Fig. 2D) rectangular with numerous minute setae on distal and lateral

254 margins. Right mandible (Fig. 2E) incisor with four well-calcified triangular teeth; outer margin

255 with tubercles and with minute setae distally. Left mandible (Fig. 2F) outer margin with distally

256 setulose tubercles; incisor with four distal teeth; lacinia mobilis as long as incisor, with four

257 teeth, setiferous lobe with four complex-tip setae; molar broad, distally serrated; palp (Fig. 2G)

258 article-1 1.1 L:W, with five inner setae; article-2 2.1 L:W with outer margin serrated, two simple

259 distal setae and row of about 14 inner setae starting from the middle of the article, decreasing in

260 length towards the distal end of the article; article-3 3.7 L:W, with five outer setae and a row of

261 about 18 setae along the inner margin. Maxillule (Fig. 2H) inner endite with five setae distally (at

262 least three setulated), inner and outer margins serrated, outer margin with tuft of setae and

263 subproximal tubercle; outer endite with eleven spines (one appearing serrated), outer margin

264 setulated. Maxilla (Fig. 2I) outer lobe of moveable endite with two subdistal simple setae and six

265 distal serrated setae, outer margin with microtrichiae; inner lobe of moveable endite with ten

266 serrated setae distally; outer lobe of fixed endite distally with three tri-furcated and three serrated

267 setae; inner lobe of fixed endite with 22 setae (at least five of them serrated). Labium (Fig. 2J, K)

268 outer and inner margins with setation distally; palp (Fig. 2K) lateral margins setulated distally

269 with three simple spines.

270 Maxilliped (Fig. 2L) coxa naked. Basis 1.1 L:W, with laterodistal seta and three subdistal long

271 setae, additionally outer margin with teeth and inner margin with proximal microtrichiae. Palp

272 article-1 0.4 L:W, with long simple seta on inner margin and one simple seta and two plumose

273 setae on outer margin; article-2 1.2 L:W, with two rows of setae on inner margin (first with 11 
274 setae and second with five setae, at least one seta plumose), and two long laterodistal setae;

275 article-3 about as long as wide, with row of about 10 setae along inner margin (at least one

276 plumose); article-4 1.3 L:W, with row of nine distal setae (at least five of them serrated) and one

277 outer seta. Endite (Fig. 2M) outer margin setulated; inner margin with three coupling hooks and

278 five short plumose setae; distal margin with nine short plumose setae/spines (some with complex

279 tip) and one long plumose seta; subdistal seta simple (not leaf-like).

280 Cheliped (Fig. 3A) basis 1.1 L:W, with plumose dorsodistal seta, simple seta ventroproximally,

281 one spine ventrally at mid-length and four long setae ventrodistally; exopod of three articles,

282 article-3 with nine plumose setae (drawn as simple for figure clarity); merus $1.2 \mathrm{~L}: \mathrm{W}$ and $0.7 \mathrm{x}$

283 basis, with one simple seta, one plumose seta, four spines and apophysis ventrally; carpus 0.9

284 L:W and 1.2x merus, with row of seven setae along dorsal margin, three setae ventrally and

285 distal apophysis; propodus $0.9 \mathrm{~L}: \mathrm{W}$ and $1.8 \mathrm{x}$ carpus, with three short setae dorsally, three setae

286 on outer surface, and one serrated inner spine near dactylus insertion; fixed finger about $0.8 \mathrm{x}$

287 propodus, with two proximal outer setae, four setae ventrally, cutting margin with two long setae

288 near dactylus insertion, four setae distally and small teeth accompanied with minute setae in

289 proximal half; dactylus just longer than fixed finger with two subdistal setae, and row of teeth

290 and spinules along the cutting edge.

291 Pereopod-1 (Fig. 3B) coxa long and with smooth margins, with two setae; basis $2.2 \mathrm{~L}: \mathrm{W}$ and

292 2.0x merus, with two ventral setae and four ventrodistal setae, row of plumose (five) and simple

293 (five) setae along dorsal margin; exopod of three articles, article-3 with 11 plumose setae;

294 ischium with three ventrodistal setae; merus 1.3 L:W and 1.1x carpus, with one dorsodistal spine,

295 one ventrodistal spine, four ventral and three dorsal setae, and four setae on inner surface; carpus

296 1.1 L:W and 1.1x propodus, with two ventrodistal spines, three setae ventrally, one short seta 
297 distally and six setae dorsally; propodus $1.5 \mathrm{~L}: \mathrm{W}$ and $1.5 \mathrm{x}$ dactylus, with three spines and four

298 setae ventrally, and with two spines and two setae dorsally; dactylus 2.9 L:W and 2x unguis,

299 with one dorsal seta and ventral apophysis; dactylus and unguis combined as long as propodus.

300 Pereopod-2 as peropod-3 (not figured).

301 Pereopod-3 (Fig. 3C) coxa with one seta; basis 2.1 L:W and 1.8x merus, with tuft of three setae

302 ventrodistally, one simple seta, three penicillate setae dorsally, and three simple setae ventrally;

303 ischium with two ventrodistal setae; merus $1.7 \mathrm{~L}: \mathrm{W}$ and $1.3 \mathrm{x}$ carpus, with one small spine and

304 one larger spine ventrodistally, one dorsodistal seta, one ventral seta, and two ventrodistal setae;

305 carpus $1.2 \mathrm{~L}: \mathrm{W}$ and $0.65 \mathrm{x}$ propodus, with one ventral subproximal spine, two ventrodistal spines,

306 one short seta, two long setae, and three spines dorsodistally; propodus $2.5 \mathrm{~L}: \mathrm{W}$ and $1.5 \mathrm{x}$

307 dactylus, with three ventroproximal spines, one ventrodistal spine, one dorsal subdistal spine,

308 one dorsodistal spine, one ventral seta, two short ventrodistal setae, two dorsal setae, and one

309 dorsodistal seta; dactylus 3.2 L:W, with ventral tooth, ventrodistal seta, and two dorsal setae;

310 unguis about $0.5 \mathrm{x}$ dactylus; together about as long as propodus.

311 Pereopod-4 (Fig. 3D) coxa with two penicillate setae; basis 2.1 L:W and 2.0x merus, with one

312 ventroproximal seta, two short setae, and one long seta ventrodistally, and two simple setae and

313 three penicillate setae dorsally; ischium with three ventrodistal setae; merus $1.5 \mathrm{~L}: \mathrm{W}$ and $0.9 \mathrm{x}$

314 carpus, with two short ventrodistal spines, two ventral setae, one ventrodistal seta, and two long

315 dorsodistal setae; carpus 1.8 L:W and as long as propodus, with two short spines and one longer

316 dorsal spine, two ventrodistal spines, two ventrodistal setae, and three dorsodistal setae;

317 propodus 3.3 L:W and 2.0x dactylus, with one penicillate dorsal seta and eight serrated setae

318 distally; dactylus damaged, 2.0x unguis, with two short setae ventrally. 
319 Pereopod-5 (Fig. 3E) coxa with one simple seta and one plumose seta; basis $2.3 \mathrm{~L}: \mathrm{W}$ and $2.2 \mathrm{x}$

320 merus, with simple ventroproximal seta, one mid-length ventral seta, one plumose seta and three

321 simple setae ventrodistally, dorsal margin with one simple seta, five plumose setae and three

322 penicillate setae; ischium with one plumose seta and one short simple seta ventrodistally; merus

323 1.7 L:W and as long as carpus, with one short ventrodistal spine, one plumose ventral seta, one

324 simple ventrodistal seta, and one plumose dorsodistal seta; carpus 1.5 L:W and 0.8x propodus,

325 with four spines increasing in size along ventral margin, and one dorsodistal spine, one plumose

326 dorsal seta, and one plumose seta and two simple dorsodistal setae; propodus $2.0 \mathrm{~L}: \mathrm{W}$ and $1.7 \mathrm{x}$

327 dactylus, with two ventral spines, three ventrodistal serrated minute spines, one serrated

328 dorsodistal spine, and one dorsodistal plumose seta; dactylus with mid-length minute ventral

329 spine, medially and dorsally with one seta, combined length of dactylus with that of unguis $0.9 x$ 330 propodus.

331 Pereopod-6 (Fig. 3F) basis 3.1 L:W and 3.4x merus, with two dorsal plumose setae and four 332 ventral plumose setae; ischium with one ventrodistal plumose seta; merus $1.3 \mathrm{~L}: \mathrm{W}$ and $0.6 \mathrm{x}$ 333 carpus, with one subdistal plumose seta dorsally and two ventrodistal plumose setae; carpus 1.9 334 L:W and 0.9x propodus, with two ventrodistal spines, one dorsodistal spine, one ventrodistal 335 simple seta, one distal simple seta, and one dorsodistal plumose seta; propodus 2.2 L:W and 1.2x 336 dactylus, with one mid-length spine ventrally, and at least nine minute serrated spines 337 ventrodistally and dorsodistally, and one dorsal mid-length penicillate seta; dactylus with 338 ventrodistal seta, ventral serration, and three dorsal setae; dactylus with mid-length minute 339 ventral spine, medially and dorsally with one seta, combined length of dactylus with that of 340 unguis $1.1 \times$ propodus. 
341 Pleopods (Fig. 3G) basal article 1.7 L:W, with one distal plumose seta; endopod just longer than

342 exopod, with two plumose setae subdistally, seven plumose setae distally, and one dorsal seta,

343 and one ventral mid-length seta; exopod with eleven plumose setae along distal end and one

344 plumose ventroproximal seta.

345 Uropod (Fig. 3H) basal article 1.8 L:W, with seven simple setae distally; exopod of three

346 segments, segment-2 with two distal setae, segment-3 with three distal setae; exopod 3.7x

347 endopod, of seven segments, some with mid-length setae apparently indicating segment fusion;

348 segment-3 with two distal setae; segment-4 with four mid-length setae, and two penicillate setae,

349 and three simple setae distally; segment-5 with two mid-length setae, and two penicillate setae,

350 and two simple setae distally; segment-7 with two penicillate setae and four simple setae distally;

351 other segments naked.

352 Distribution. Species is known only from the type locality, offshore Portland (Australia), from a 353 depth of $49.6 \mathrm{~m}$ and habitats rich in red algae.

354

355 Discussion

356 Distribution of Chondropodinae

357 Depth and habitat

358 Chondropodinae, as the other metapseudids, are mostly represented by shallow-water taxa whose

359 vertical distributions rarely exceed the edge of the continental shelf (Table 1). To date, only three

360 species have been recorded from greater depths, namely Julmarichardia thomassini Guţu, 1989

361 found at $250 \mathrm{~m}$, Calozodion pabisi Jakiel \& Jóźwiak, 2015 found at $386 \mathrm{~m}$, and Julmarichardia

362 alinati Guţu, 1989 recovered in a surprisingly wide depth range from 6 to $450 \mathrm{~m}$ (Table 1).

363 Chondropodinae and other members of the family Metapseudidae are usually associated with 
364 coral reefs or hydroid colonies (Sieg, 1986a; Stęień \& Błażewicz-Paszkowycz, 2013), but also

365 occur in or on a variety of different substrata, e.g., sand, silt clay, rubble, algae, or dead corals 366 (Table 1).

367 Geographical distribution

368 Chondropodinae are most diversified in the Atlantic and represented by 17 species. The highest 369 number of species (six) has been recorded for the relatively restricted areas of the Eastern Gulf of 370 Mexico, Cuba, Haiti, and Southeast Mexico (Richardson, 1902; Gardiner, 1973; Guţu, 1984;

371 Guţu, 2002; Guţu, 2006b; Guţu, 2009). Furthermore, five Chondropodinae are known from East 372 African coasts (Barnard, 1914; Barnard, 1920; Guţu, 1989b; Guţu, 2014), and four species were

373 found in West Africa (Guţu, 2006a; Menioui, 2013). The genera of Chondropodinae are widely 374 distributed and usually present in more than one marine basin. For example, Julmarichardia was 375 found in the Mozambique Channel, on the Malaysian coast, in Northwest Australia, and in the 376 Northeast Atlantic. Calozodion was found on the Brazilian coast, off Angola, off Mauritania, in 377 Malaysia, in the Caribbean Sea, and in the Gulf of Mexico (Figs 4 and 5). Two non-monotypic 378 genera of Chondropodinae, Vestigiramus and Chondropodus, have a restricted distribution. 379 Vestigiramus is represented by three species that occur along the East coast of South America, 380 and Chondropodus, with two species, has been recorded from the coast of Mauritania. The 381 distribution of Chondropodinae is clearly limited to tropical, subtropical, and, to some extent, 382 temperate waters; likewise, they are entirely absent in higher latitudes (Figs 4 and 5). The most 383 northerly record is held by Julmarichardia dollfusi (Guţu, 1989), situated in the subboreal zone 384 (latitude $49^{\circ} \mathrm{N}$ ) off Jersey in the Northeast Atlantic (English Channel) (Gutu, 1989a). Until now, 385 the most southerly records of Chondropodinae have been made by Barnard, who described 386 Julmarichardia deltoides (Barnard, 1914) from the Great Fish Point Lighthouse (Port Alfred, 
387 South Africa) and Trichapseudes tridens Barnard, 1920 offshore of East London (South Africa)

388 (approximately $33^{\circ} \mathrm{S}$; coordinates are not specified in the original descriptions) (Barnard, 1914;

389 Barnard, 1920). As of this record, Muvi schmallenbergi is the southernmost record of the 390 subfamily, found at approximately $38^{\circ} \mathrm{S}$. The Atlantic sectors of the Arctic and the Antarctic are 391 among the most studied areas of the World Ocean (Sieg, 1986b; Sieg, 1986c; Bird, 2010; 392 Błażewicz-Paszkowycz, 2014; Jakiel, Stępien' \& Błażewicz, 2018); thus, the absence of the 393 Chondropodinae in polar regions cannot be explained by biased sampling efforts.

394 The longitudinal gradient in diversity, observed in many groups of marine invertebrates 395 (decapods, gastropods, and bivalves) or vertebrates (e.g., fishes), point to a peak in the tropics 396 and a decrease towards the poles (Clarke \& Crame, 2010; Rabosky et al., 2018). The highest 397 diversity around the equator is justified by the larger area and the longer evolutionary time of the 398 tropical regions, where diversity is supported by higher rates of speciation and lower extinction rates (Mittelbach et al., 2007; Brown, 2014). Cenozoic glaciations interrupted by interglacial 400 events are stated as the main factor responsible for extinctions of shallow-water taxa in polar 401 regions (Clarke \& Crame, 2010; Thatje, 2012). Recolonization of the vacant habitats of the Antarctic shelf is assumed to be limited for tropic or temperate fauna because of their physiological adaptation to warmer waters (Thatje, 2012; Brown, 2014). Hence, Brown (2014) remarked that tropical species and lineages have a long evolutionary history in relatively equable 405 environments and may not tolerate several abiotic stresses (e.g., low temperature and extreme 406 seasonality).

407 The pantropical and pantemperate distribution of tanaidacean families and their absence in high 408 latitudes has previously been reported for most shallow-water families of Apseudomorpha 409 (Błażewicz-Paszkowycz, 2014) and some plesiomorphic families of Tanaidomorpha, such as 
410 Tanaididae, Pseudozeuxidae, Paratanaidae, and Leptocheliidae (Błażewicz-Paszkowycz, Bamber

$411 \&$ Anderson, 2012). Sieg (1992) stated that tropical or temperate Tanaidacea that became extinct

412 during glaciations were replaced by deep-sea taxa because of similar temperature regimes in the

413 abyssal and the Antarctic shelf (polar emergence). He argued that tanaidaceans which evolved

414 before the Eocene were theoretically "ready" to colonize vacant Antarctic habitats and that the

415 Antarctic shallow-water tanaidaceans are dominated by phylogenetically young taxa which lack

416 functional eyes, evidencing their deep-sea origin (Sieg, 1992). Błażewicz-Paszkowycz (2014) has

417 supplemented Sieg's hypothesis by indicating that some tanaidaceans might have survived the

418 glaciations in the deeper shelf or slope refugia or colonized the Antarctic via the Scotia Arc. This

419 idea is strongly supported by the presence of representatives of typically tropical families in

420 Antarctica, such as Paratanais oculatus (Paratanaidae), Allotanais hirsutus (Tanaididae), and

421 Synapseudes aflagellatus Sieg, 1986 (Metapseudidae).

422 The Arctic is less thermally isolated than the Antarctic, which is surrounded by the Antarctic

423 Circumpolar Current (ACC). Furthermore, the Arctic is supported by the transitional zones to the

424 south, where the temperate Atlantic waters merge and mix with the polar waters (Loeng et al.,

425 2005; Stepanjants et al., 2006). Also, warm water masses transported to the Arctic by the

426 Atlantic currents promote the distribution of temperate fauna to the polar zone (McBride et al.,

427 2014; Csapó et al., 2021). Although the Arctic has a more recent history of glaciation, dated to

428 about $2.5 \mathrm{Ma}$, than the Antarctic $(>20 \mathrm{Ma})$, the paucity of the temperate and tropical fauna in the

429 Northern Hemisphere is comparable to that of the Southern Hemisphere. Although in the Arctic,

430 the tanaidaceans share some species with the temperate Atlantic and are characterized by a lower

431 level of endemism (Sieg, 1986a), tropical/temperate shallow-water apseudomorphs are still 
432 underrepresented, including Chondropodinae (Stepień et al., 2018) and plesiomorphic families of

433 Tanaidomorpha.

\section{Conclusions}

435 A new tanaidacean genus and species from the subfamily Chondropodinae is described, which 436 can easily be distinguished from other Chondropodinae by having equally long antennular 437 flagella. Also, Muvi schmallenbergi is the third Chondropodinae species recorded from Australia 438 after Bamberus jinigudirus and Julmarichardia gutui.

439 Morphological analysis of the genus Deidamiapseudes indicated the transfer of this genus from 440 Chondropodinae (Metapseudidae) to Apseudoidea incertae sedis. One of the crucial arguments 441 supporting this reclassification was the absence of a row of setae on the pereopod-1 basis.

442 The lack of Chondropodinae in higher latitudes suggests their extinction during glaciation events 443 and their physiology adapted to tropical/temperate conditions, resulting in their inability to 444 recolonize polar regions.

\section{Acknowledgments}

447 The authors would like to thank Gary Poore for collecting the material and Melanie Mackenzie and Joanne Taylor from the Museum of Victoria for making the material available for the study. We also thank Andrés G. Morales-Núñez, Richard Heard, and an anonymous reviewer for their constructive comments on the manuscript.

\section{References}

Araújo-Silva CL, Larsen K. 2012. Tanaidacea from Brazil. III New records and description of a new species collected from REVIZEE-NE Program. Nauplius 20 (2): 87-105. 
455 Băcescu M. 1981. Contribution to the knowledge of the Monokonophora (Crustacea, 456 Tanaidacea) of the eastern Australian coral reefs. Revue Roumaine de Biologie (Biologie 457 animale) 26: 111-120.

458 Bamber RN. 2005. The tanaidaceans (Arthropoda: Crustacea: Peracarida: Tanaidacea) of 459 Esperance, Western Australia, Australia. In: Wells FE, Walker DI, Kendrick GA, eds. The 460 Marine Flora and Fauna of Esperance, Western Australia, Western Australian Museum: Perth, 461 613-728,

462 Bamber RN. 2008. Tanaidaceans (Crustacea: Peracarida: Tanaidacea) from Moreton Bay, 463 Queensland. In: Davie PJF, Phillips JA, eds. Proceedings of the Thirteenth International Marine 464 Biological Workshop, The Marine Fauna and Flora of Moreton Bay, Queensland. Memoirs of 465 the Queensland Museum - Nature: Queensland, 143-217.

Bamber RN. 2013. A re-assessment of Konarus Bamber, 2006 and sympatric leptocheliids from 467 Australasia, and of Pseudoleptochelia Lang, 1973 (Crustacea: Peracarida: Tanaidacea). Zootaxa 468 3694(1): 1-39.

469 Bamber RN, Błażewicz-Paszkowycz M. 2013. Another inordinate fondness: diversity of the 470 tanaidacean fauna of Australia, with description of three new taxa. Journal of Natural History 471 47(25-28): 1767-1789. https://doi.org/10.1080/00222933.2012.742164

472 Bamber R, Sheader M. 2005. Apseudomorph Tanaidacea (Crustacea: Peracarida) from shallow 473 waters off Sabah, Malaysia. Systematics and Biodiversity 26 (3): 281-303.

474 Barnard KH. 1914. Contributions to the crustacean fauna of South Africa. 3. Additions to the 475 marine Isopoda, with notes on some previously incompletely known species. Annals of the South 476 African Museum 10 (11): 325a-358a, 359-440. 
477 Barnard KH. 1920. Contributions to the crustacean fauna of South Africa. No. 6.- Further 478 additions to the list of marine Isopoda. Annals of the South African Museum 17(5): 319-438.

479 Bird GJ. 2010. Tanaidacea (Crustacea, Peracarida) of the North-east Atlantic: the 480 Agathotanaidae of the AFEN, BIOFAR and BIOICE projects, with a description of a new 481 species of Paragathotanais Lang. Zootaxa 2730: 1-22.

482 Błażewicz-Paszkowycz M. 2014. Tanaidacea. In: De Broyer C, Koubbi P, Griffiths H, Danis B, 483 David B, eds, Biogeographic Atlas of the Southern Ocean. Scientific Committee on Antarctic 484 Research: Cambridge, 173-180.

485 Błażewicz-Paszkowycz M, Bamber RN. 2009. A new genus of a new Austral family of 486 paratanaoid tanaidacean (Crustacea: Peracarida: Tanaidacea), with two new species. Memoirs of 487 Museum Victoria 66: 5-15.

Błażewicz-Paszkowycz M, Bamber RN. 2012. The shallow-water Tanaidacea (Arthropoda:

Malacostraca: Peracarida) of the Bass Strait, Victoria, Australia (other than the Tanaidae). Memoirs of Museum Victoria 69: 1-235.

491

492

493

494

495

496

497

498

499

Błażewicz-Paszkowycz M, Bamber R, Anderson G. 2012. Diversity of Tanaidacea (Crustacea: Peracarida) in the World's Oceans - How Far Have We Come? PLoS ONE 7(4): e33068. https://doi.org/10.1371/journal.pone.0033068

Błażewicz-Paszkowycz M, Bamber RN, Jóźwiak P. 2013. Tanaidaceans (Crustacea: Peracarida) from the SoJaBio joint expedition in slope and deeper waters in the Sea of Japan. Deep-Sea Research II 111: 325-332. https://doi.org/10.1016/j.dsr2.2014.08.021

Błażewicz-Paszkowycz M, Zemko K. 2009. A new species of Metatanais Shiino, 1952 (Crustacea, Tanaidacea, Paratanaoidea) from Australian coral reefs, with a redefinition of the genus. ZooKeys 18: 129-141. 
500 Bochert R. 2012. Apseudomorph Tanaidacea from the continental shelf of Angola and Namibia

501 with descriptions of three new species. Zootaxa 3583: 31-50.

502 Boesch DF. 1973. Three new tanaids (Crustacea, Tanaidacea) from southern Queensland. Pacific 503 Science 27: 168-188.

504 Brown JH. 2014. Why are there so many species in the tropics? Journal of Biogeography 41: 8505 22. https://doi.org/10.1111/jbi.12228

506 Clarke A, Crame JA. 2010. Evolutionary dynamics at high latitudes: speciation and extinction in 507 polar marine faunas. Philosophical Transactions of the Royal Society of London B 365: 36555083666.

509 Csapó HK, Grabowski M, Węsławski JM. 2021. Coming home - Boreal ecosystem claims 510 Atlantic sector of the Arctic. Science of The Total Environment 771: 144817. 511 https://doi.org/10.1016/j.scitotenv.2020.144817

512 Edgar GJ. 1997. A new genus and three new species of apseudomorph tanaidacean (Crustacea) 513 from the Darwin region. In: Hanley JR, Caswell G, Megirian D, Larson HK, eds, Proceedings of 514 the Sixth International Marine Biological Workshop. The Marine Flora and Fauna of Darwin 515 Harbour, Northern Territory, Australia, Darwin: 279-299.

516 Edgar GJ. 2008. Shallow water Tanaidae (Crustacea: Tanaidacea) of Australia. Zootaxa 1836: 151792.

518 Edgar GJ. 2012. New Leptocheliidae (Crustacea: Tanaidacea: Tanaidomorpha) from Australian 519 seagrass and macro-algal habitats, and a redescription of the poorly-known Leptochelia ignota 520 from Sydney Harbour. Zootaxa 3276: 1-37. https://doi.org/10.11646/zootaxa.3926.4.10

521 Gardiner LF. 1973. Calozodion wadei, a new genus and species of apseudid tanaidacean

522 (Crustacea) from Jamaica, West Indies . Journal of Natural History 7: 499-507. 
523 Gellert M, Błażewicz M. 2018. New species of Anarthruridae (Tanaidacea: Crustacea) of the

524 western Australian slope. Marine Biodiversity 49: 583-601.

525 Guţu M. 1984. Contribution to the knowledge of the genus Calozodion (Crustacea, Tanaidacea).

526 Travaux du Muséum National d'Histoire naturelle “Grigore Antipa” 26: 35-43.

527 Guţu M. 1989a. La description de Calozodion Dollfusi, espèce nouvelle de tanaïdacés

528 (Crustacea) provenant des eaux européennes de 1'Atlantique. Travaux du Muséum National 529 d'Histoire naturelle "Grigore Antipa” 30: 129-133.

530 Guţu M. 1989b. Tanaidacea (Crustacea) collected by the "Benthédi” French Expedition (1977) in 531 the South-Western Indian Ocean. I. Travaux du Muséum National d'Histoire naturelle "Grigore 532 Antipa”30: 135-160.

533 Guţu M. 1996. Tanaidaceans (Crustacea, Peracarida) from Brazil, with description of new taxa 534 and systematical remarks on some families. Travaux du Muséum National d'Histoire naturelle 535 “Grigore Antipa” 36: 23-133.

536 Guţu M. 2002. New apseudid and metapseudid taxa (Crustacea: Tanaidacea) from the Gulf of 537 Mexico, and new diagnoses of some genera. Travaux du Muséum National d'Histoire naturelle 538 “Grigore Antipa” 44: 41-68.

539 Guţu M. 2006a. New Apseudomorph Taxa (Crustacea, Tanaidacea) of the World Ocean. Curtea 540 Veche, Bucharest.

541 Guţu M. 2006b. A new metapseudid genus and species (Crustacea: Tanaidacea) from the 542 northeast of the Hispaniola Island (Dominican Republic). Travaux du Muséum National 543 d'Histoire naturelle "Grigore Antipa" 49: 49-57. 
544 Guţu M. 2008. On the systematic position of the genera Trichapseudes Barnard and

545 Hoplomachus Guţu, 2002 and the description of a new metapseudid subfamily (Crustacea:

546 Tanaidacea: Apseudomorpha). Travaux du Museum National d'Histoire Naturelle, 51, 71-77.

547 http://dx.doi.org/10.2478/v10191-010-0004-9

548 Guţu M. 2009. A contribution to the knowledge of metapseudids. Description of a new genus

549 and three new species from the Caribbean Sea and the Indian Ocean (Crustacea: Tanaidacea:

550 Apseudomorpha). Travaux du Muséum National d'Histoire naturelle “Grigore Antipa” 52: 101$551 \quad 125$.

552 Guţu M. 2014. Two new species of the genus Calozodion Gardiner (Crustacea: Tanaidacea: 553 Apseudomorpha) from the Adriatic sea and the Indian Ocean, and the reclassification of $C$. 554 dollfusi Guţu, 1989 in the genus Julmarichardia Guţu. Travaux du Muséum National d'Histoire 555 Naturelle “Grigore Antipa” 57 (1): 13-26.

556 Haswell WA. 1882a. On some new Australian marine Isopoda- Part II. Proceedings of the 557 Linnean Society of New South Wales 6: 181-197.

558 Haswell WA. 1882b. Description of a new species of Apseudes. Proceedings of the Linnean 559 Society of New South Wales 6: 748-749.

560 Haswell WA. 1885. Revision of the Australian Isopoda. Proceedings of the Linnean Society of 561 New South Wales 9: 1001-1016.

562 Jakiel A, Stępień A, Jóźwiak P, Serigstad B, Błażewicz-Paszkowycz M. 2015. First record of 563 Tanaidacea (Crustacea) from a deep-sea coral reef in the Gulf of Guinea. Zootaxa 3995(1): 203564228.

565 Jakiel A, Stępień A, Błażewicz M. 2018. A tip of the iceberg - Pseudotanaidae (Tanaidacea)

566 diversity in the North Atlantic. Marine Biodiversity 48: 859-895. 
567 Jóźwiak P, Jakiel A. 2012. A new genus and new species of Agathotanaidae (Crustacea,

568 Tanaidacea) from West Australia. ZooKeys 243: 15-26.

569 Larsen K, Shimomura M. 2006. Tanaidacea (Crustacea: Peracarida) from Japan. I.

570 Apseudomorpha from the East China Sea, Seto Inland Sea, and Nansei Islands. Zootaxa 1341: $57129-48$.

572 Loeng H, Brander K, Carmack E, Denisenko S, Drinkwater K, Hansen B, Kovacs K, Livingston 573 P, McLaughlin F, Sakshaug E. 2005. Chapter 9: Marine systems. In: Arctic Climate Impact 574 Assessment. Cambridge University Press: Cambridge, UK, 451-538.

575 McBride MM, Dalpadado P, Drinkwater KF, Godø OR, Hobday AJ, Hollowed AB, Kristiansen

576 T, Murphy EJ, Ressler PH, Subbey S, Hofmann EE, Loeng H. 2014. Krill, climate, and 577 contrasting future scenarios for Arctic and Antarctic fisheries. ICES Journal of Marine Science 57871 (7): 1934-1955. https://doi.org/10.1093/icesjms/fsu002

579 Menioui M. 2013. Calozodion moyas, a new metapseudid species (Crustacea: Tanaidacea: 580 Apseudomorpha) from the Moroccan Atlantic Coast. Travaux du Muséum National d'Histoire 581 naturelle "Grigore Antipa” 36 (1): 9-18.

582 Mittelbach GG, Schemske DW, Cornell HV, Allen AP, Brown JM, Bush MB, Harrison SP, 583 Hurlbert AH, Knowlton N, Lessios HA, McCain CM, McCune MR, McDade LA, McPeek MA, 584 Near TJ, Price TD, Ricklefs RE, Roy K, Sax DF, Schluter D, Sobel JM, Turelli M. 2007. 585 Evolution and the latitudinal diversity gradient: speciation, extinction and biogeography. Ecology 586 Letters 10: 315-331.

587 Poore GCB., Avery L, Błażewicz-Paszkowycz M, Browne J, Bruce NL, Gerken S, Glasby C, 588 Greaves E, McCallum AW, Staples D, Syme A, Taylor J, Walker-Smith G, Warne M, Watson C, 589 Williams A, Wilson RS, Woolley S. 2015. Invertebrate diversity of the unexplored marine 
590 western margin of Australia: taxonomy and implications for global biodiversity. Marine 591 Biodiversity 45: 271. https://doi.org/10.1007/s12526-014-0255-y

592 Rabosky DL, Chang J, Title PO, Cowman PF, Sallan L, Friedman M, Kaschner K, Garilao C, 593 Near TJ, Coll M, Alfaro ME. 2018. An inverse latitudinal gradient in speciation rate for marine 594 fishes. Nature 559: 392-395. https://doi.org/10.1038/s41586-018-0273-1

595 Richardson H. 1902. The marine and terrestrial isopods of the Bermudas, with descriptions of 596 new genera and species. Transactions of the Connecticut Academy of Sciences 11: 277-310.

597 Ritger RK, Heard RW. 2007. Julmarichardia gutui, a new species of Apseudomorph 598 Tanaidacean (Crustacea: Malacostraca: Peracarida) from the Australian northwest continental 599 shelf. Zootaxa 1559: 59-68.

600 Sganga DE, Roccatagliata D. 2016. A new genus and species of Apseudomorpha (Crustacea: 601 Tanaidacea) from the Mar del Plata submarine Canyon, South West Atlantic, and replacement of 602 the preoccupied name Hoplomachus Guţu 2002. Marine Biodiversity 46 (3): 687-698.

603 Sieg J. 1986a. Distribution of the Tanaidacea: Synopsis of the known data and suggestions on 604 possible distribution patterns. In: Gore RH, Heck KL, eds. Crustacean Biogeography605 Crustacean Issues 4. Rotterdam: A.A. Balkema, 165-194.

606 Sieg J. 1986b. Crustacea Tanaidacea of the Antarctic and the Subantarctic. 1. On material 607 collected at Tierra del Fuego, Isla de los Estados, and the west coast of the Antarctic Peninsula. 608 In: Korniker LS, ed. Biology of the Antarctic Seas 18. Volume 45 in the Antarctic Research 609 Series. Washington, D.C., American Geophysical Union, Washington, D.C., 1-180.

610 Sieg J. 1986c. Tanaidacea (Crustacea) von der Antarktis und Subantarktis. II. Tanaidacea 611 gesammelt von Dr. J.W. Wägele während der Deutschen Antarktis Expedition 1983. 612 Mitteilungen aus der Zoologischen Museum der Universität Kiel 2 (4): 1-80. 
613 Sieg J. 1992. On the origin and age of the Antarctic tanaidacean fauna. In: Gallardo VA, Ferretti 614 O, Moyano HI, eds. Oceanografía en Antártica. Concepción: Centro Eula, 421-429.

615 Sieg J. 1993. Remarks on the Tanaidacea (Crustacea: Isopoda) of Australia: on Bilobatus 616 crenulatus gen. et sp. nov., [sic] from Port Darwin. The Beagle, Records of the Northern 617 Territory Museum of Arts and Sciences 10(1): 45-54.

618 Stepanjants S, Cortese G, Kruglikova S, Bjørklund K. 2006. A review of bipolarity concepts: 619 History and examples from Radiolaria and Medusozoa (Cnidaria). Marine Biology Research 2: 620 200-241. https://doi.org/10.1080/17451000600781767

621 Stępień A, Błażewicz-Paszkowycz M. 2009a. Longiflagrum amphibium, a new estuarine 622 apseudomorph tanaid (Crustacea, Peracarida) from north-western Australia. ZooKeys 18: 161623170.

624 Stępień A, Błażewicz-Paszkowycz M. 2009b. Two new species of the genus Tanzanapseudes 625 Băcescu, 1975 (Tanaidacea: Apseudomorpha: Tanzanapseudidae) from mid-west Australia. 626 Zootaxa 2283: 40-50.

627 Stępień A, Błażewicz-Paszkowycz M. 2013. Four new species and two new genera of 628 Metapseudidae (Crustacea: Tanaidacea: Apseudomorpha) from Australian coral reefs. Zootaxa $629 \quad 3717(4): 559$.

630 Stępień A, Pabis K, Błażewicz M (2018) Small-scale species richness of the Great Barrier Reef 631 tanaidaceans — results of the CReefs compared with worldwide diversity of coral reef 632 tanaidaceans. Marine Biodiversity 49: 1169. https://doi.org/10.1007/s12526-018-0894-5

633 Thatje S. 2012. Effects of Capability for Dispersal on the Evolution of Diversity in Antarctic 634 Benthos. Integrative and Comparative Biology 52: 470-482. 
635 Whitelegge T. 1901. Scientific results of the trawling expedition of H.M.C.S. "Thetis" on the 636 coast of New South Wales. Crustacea. Part II. Isopoda. Part I. Memoirs of the Australian 637 Museum 4: 203-225.

638 World Register of Marine Species. Available from http://www.marinespecies.org [accessed 31 639 July 2019].

640

641 
Figure 1

Muvi schmallenbergi sp. nov. holotype female (cat. no. MNV J74649), length $4.5 \mathrm{~mm}$. Habitus illustration.

(A) Body dorsal view. (B) Body lateral view. Scale bar $=1 \mathrm{~mm}$. Photographs: Magdalena Błażewicz. 


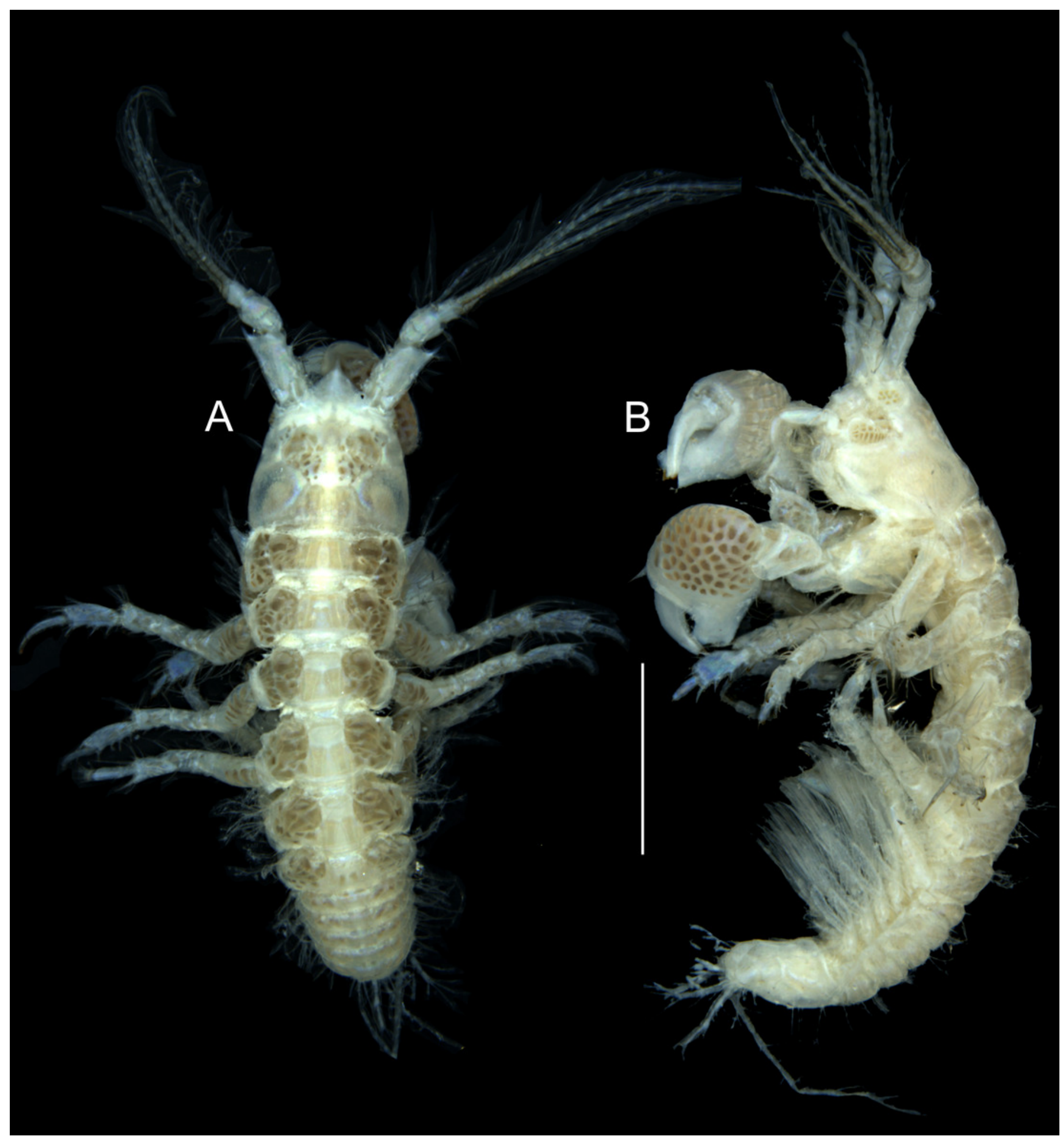


Figure 2

Muvi schmallenbergi sp. nov. paratype female (cat. no. MNV J74648). Antennule, antenna, and mouth parts illustrations.

A) Antennule. (B) Antenna. (C) Rostrum. (D) Labrum. (E) Right mandible. (F) Left mandible.

(G) Mandibular palp. (H) Maxillule. (I) Maxilla. (J) Labium. (K) Labial palp. (L) Maxilliped. (M) Maxillipedal endite. Scale bars $=0.1 \mathrm{~mm}$. 


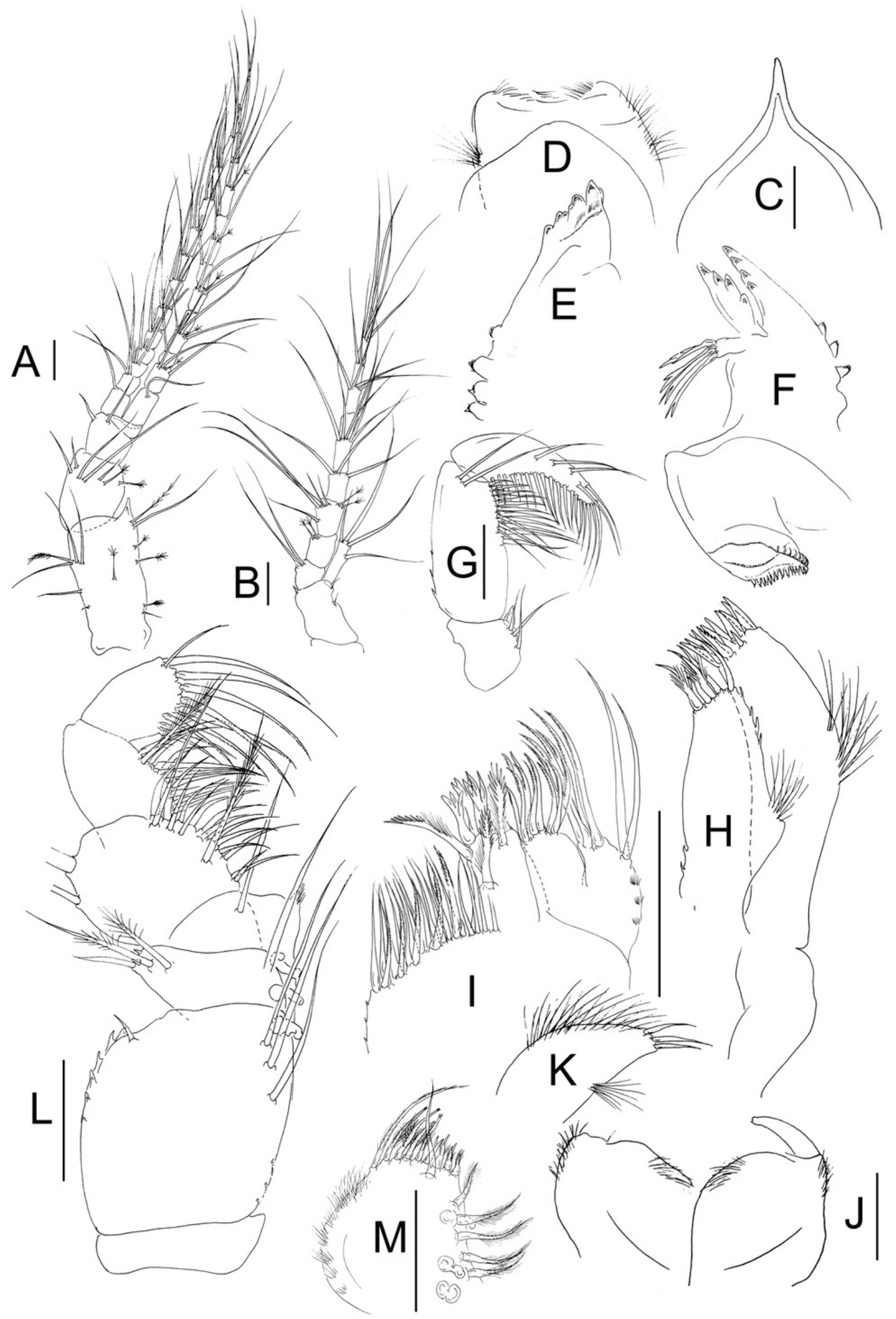


Figure 3

Muvi schmallenbergi sp. nov. paratype female (cat. no. MNV J74648). Cheliped and pereopods illustrations.

(A) Cheliped. (B) Pereopod-1. (C) Pereopod-3. (D) Pereopod-4. (E) Pereopod-5. (F)

Pereopod-6. (G) Pleopod. (H) Uropod. Scale bars $=0.1 \mathrm{~mm}$. 


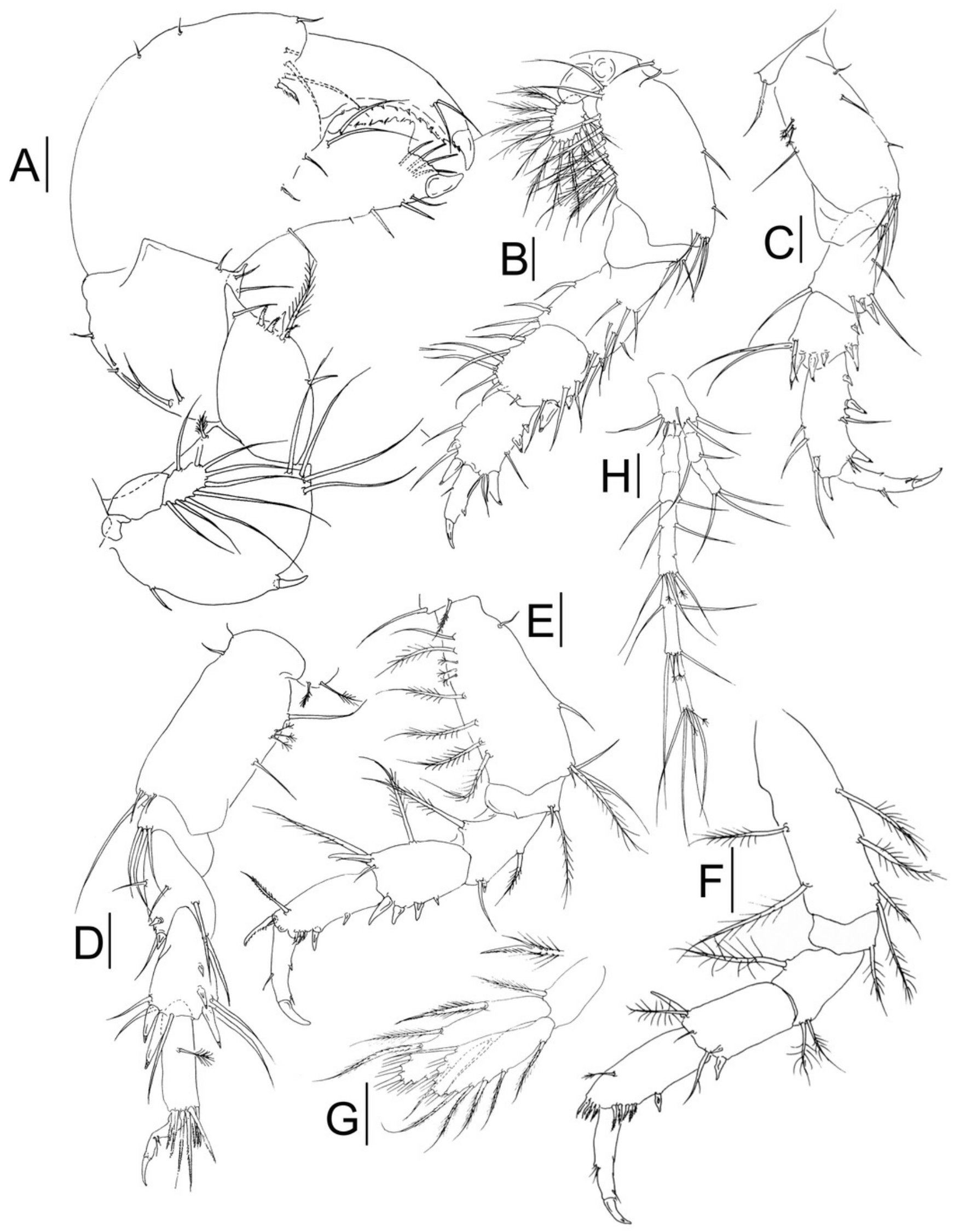


Figure 4

Distribution of Chondropodinae (1).

Circle - genus Bamberus represented only by $B$. jinigudirus. Triangle - genus Muvi represented only by $M$. schmallenbergi. Diamond - genus Calozodion: light green - $C$. bacescui; yellow - C. bogoescui; red - C. dominiki; purple - $C$. heardi; blue -C. moyas; orange - C. multispinosum; green - C. pabisi; pink - C. simile; light blue - C. singularis; brown - C. suluk; black - C. tanzaniense; light red - C. wadei. Square - genus Chondropodus: blue Ch. curvispinus; green - Ch. rectispinus.

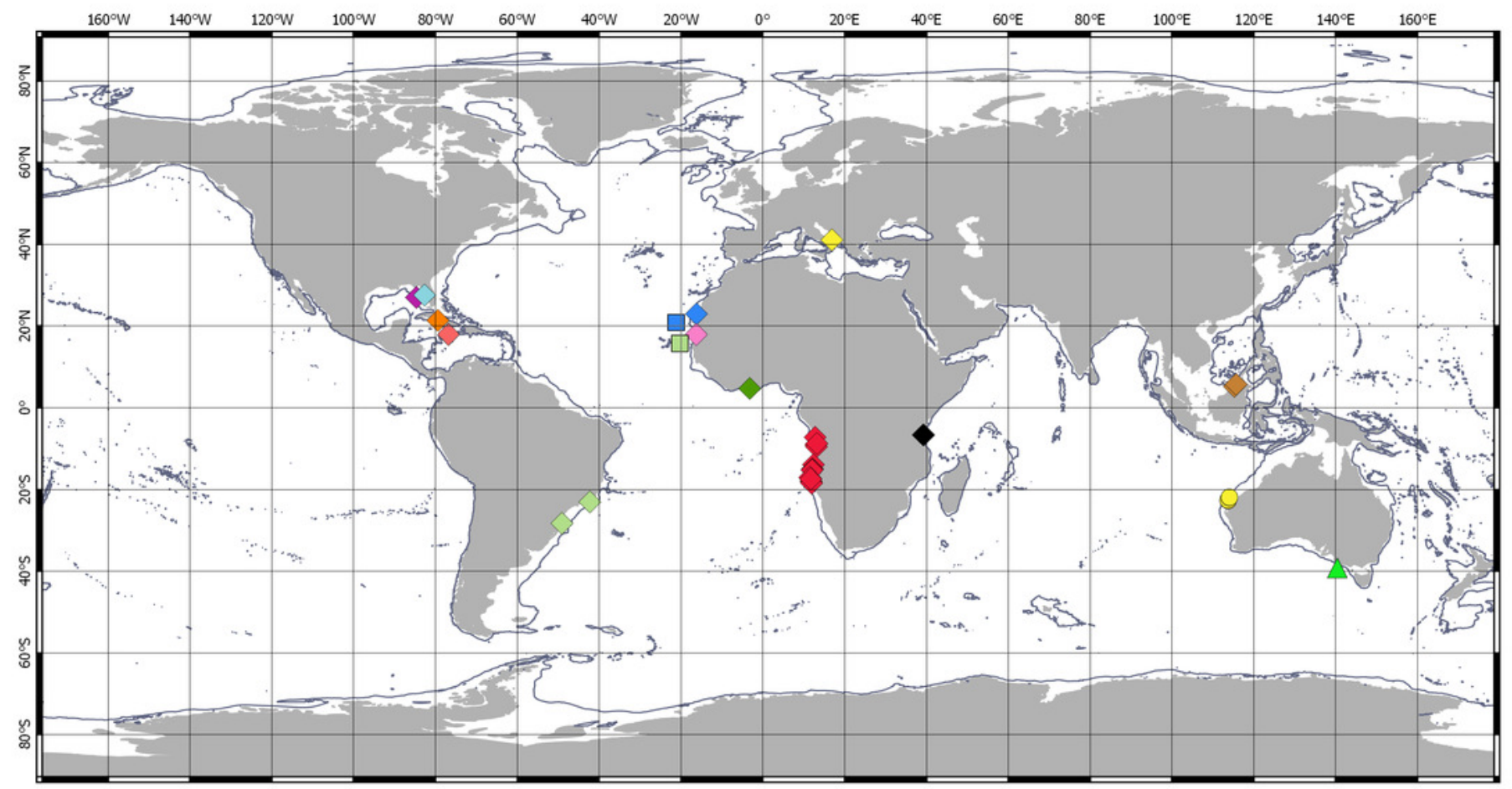


Figure 5

Distribution of Chondropodinae (2).

Circle - genus Hoplopolemius: yellow - H. propinquus; red - H. toyoshious; blue $-H$. triangulatus. Triangle - genus Julmarichardia: green - J. alinati; yellow - J. bajau; orange J. deltoides; red - J. dollfusi; black - J. gutui; blue - J. thomassini. Diamond - genus Trichapseudes represented only by $T$. tridens. Pentagon - genus Vestigiramus: red - $V$. antillensis; green - V. codreanui; orange - Vestigiramus sp. Araujo-Silva \& Larsen, 2012. Square - genus Zaraza represented only by Z. linda.

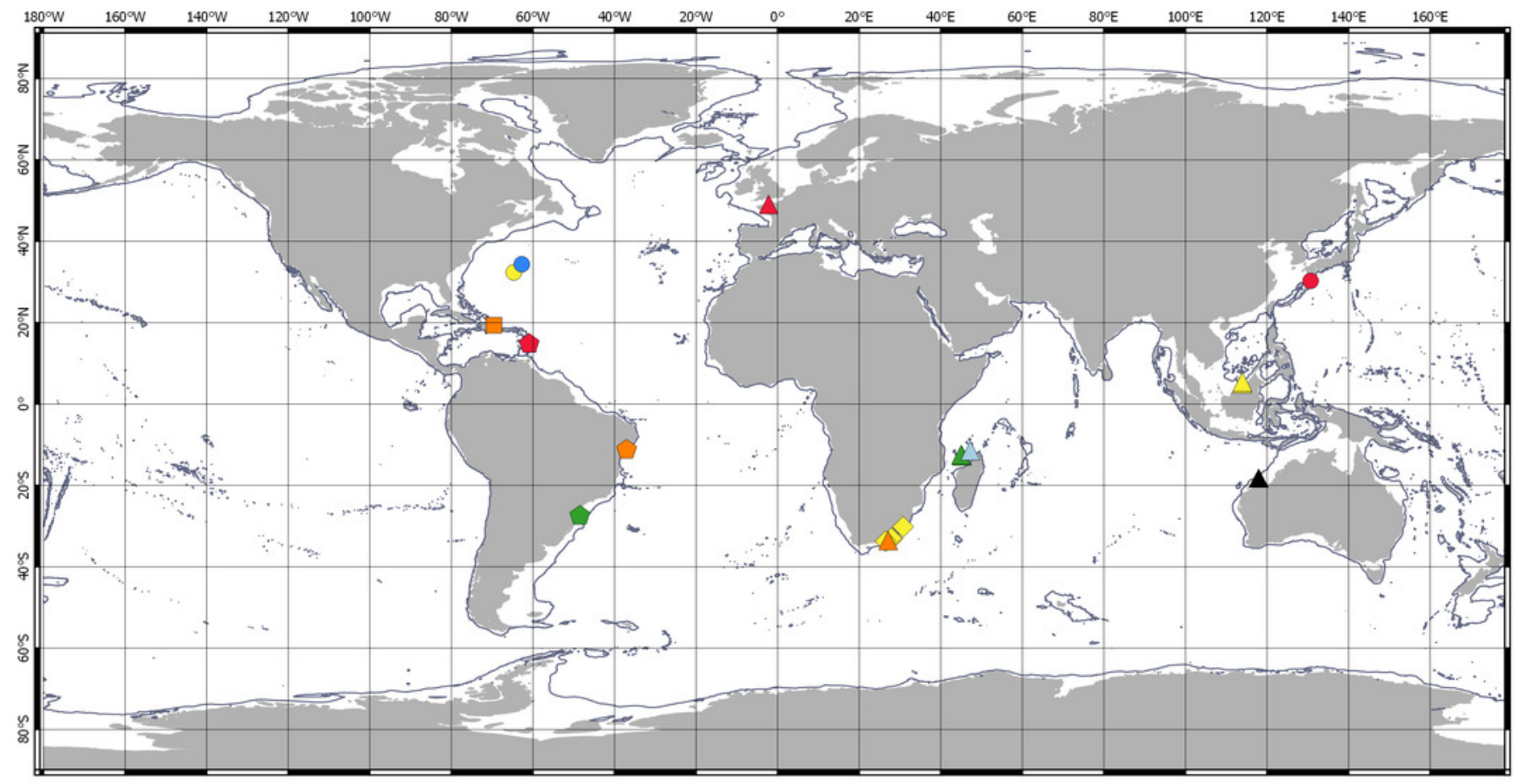




\section{Table $\mathbf{1}$ (on next page)}

Depth and sediment type for known Chondropodinae species.

Hyphen was used when the collection details were not specified in paper with description of species. 


\begin{tabular}{|c|c|c|c|}
\hline Species & Depth [m] & Sediment & References \\
\hline $\begin{array}{l}\text { Bamberus } \\
\text { jinigudirus Stępień } \\
\text { \& Błażewicz- } \\
\text { Paszkowycz, } 2013\end{array}$ & $4-12$ & $\begin{array}{l}\text { sand, fine rubble in } \\
\text { groove, dead Acropora, } \\
\text { finger rubble }\end{array}$ & $\begin{array}{l}\text { Stepień \& } \\
\text { Btażewicz- } \\
\text { Paszkowycz, } \\
2013\end{array}$ \\
\hline $\begin{array}{l}\text { Calozodion bacescui } \\
\text { Guţu, } 1996\end{array}$ & $29-50$ & $\begin{array}{l}\text { sandy substratum with } \\
\text { biogenic gravel, } \\
\text { limestone concretions } \\
\text { and algae }\end{array}$ & Guţu, 1996 \\
\hline $\begin{array}{l}\text { Calozodion } \\
\text { bogoescui Guţu, } \\
2014\end{array}$ & shallow waters & - & Guţu, 2014 \\
\hline $\begin{array}{l}\text { Calozodion dominiki } \\
\text { Bochert, } 2012\end{array}$ & $26-117$ & - & Bochert, 2012 \\
\hline $\begin{array}{l}\text { Calozodion heardi } \\
\text { Guţu, } 2002\end{array}$ & - & - & Guţu, 2002 \\
\hline $\begin{array}{l}\text { Calozodion moyas } \\
\text { Menioui, } 2013\end{array}$ & 6 & - & Menioui, 2013 \\
\hline $\begin{array}{l}\text { Calozodion } \\
\text { multispinosum Guţu, } \\
1984\end{array}$ & 22 & dark grey mud & Guţu, 1984 \\
\hline $\begin{array}{l}\text { Calozodion pabisi } \\
\text { Jakiel \& Jóźwiak, } \\
2015\end{array}$ & 386 & Lophelia reef & $\begin{array}{l}\text { Jakiel et al., } \\
2015\end{array}$ \\
\hline $\begin{array}{l}\text { Calozodion simile } \\
\text { Guţu, } 2006\end{array}$ & - & - & Guţu, 2006a \\
\hline $\begin{array}{l}\text { Calozodion } \\
\text { singularis Guţu, } \\
2002\end{array}$ & - & - & Guţu, 2002 \\
\hline $\begin{array}{l}\text { Calozodion suluk } \\
\text { Bamber \& Sheader, } \\
2005\end{array}$ & $23-35$ & $\begin{array}{l}2 \% \text { gravel, } 75-78 \% \\
\text { sand, } 9-12 \% \text { silt, } 10- \\
11 \% \text { clay }\end{array}$ & $\begin{array}{l}\text { Bamber \& } \\
\text { Sheader, } 2005\end{array}$ \\
\hline $\begin{array}{l}\text { Calozodion } \\
\text { tanzaniense Guţu, } \\
2014\end{array}$ & shallow waters & - & Guţu, 2014 \\
\hline $\begin{array}{l}\text { Calozodion wadei } \\
\text { Gardiner, } 1973\end{array}$ & 6.1 & fine sand, silt and clay & Gardiner, 1973 \\
\hline $\begin{array}{l}\text { Chondropodus } \\
\text { curvispinus Guţu, } \\
2006\end{array}$ & - & - & Guţu, 2006a \\
\hline $\begin{array}{l}\text { Chondropodus } \\
\text { rectispinus Guţu, }\end{array}$ & - & - & Guţu, 2006a \\
\hline
\end{tabular}




\begin{tabular}{|c|c|c|c|}
\hline 2006 & & & \\
\hline $\begin{array}{l}\text { Hoplopolemius } \\
\text { propinquus } \\
\text { (Richardson, 1902) }\end{array}$ & - & - & $\begin{array}{l}\text { Richardson, } \\
1902\end{array}$ \\
\hline $\begin{array}{l}\text { Hoplopolemius } \\
\text { toyoshious (Larsen } \\
\text { \& Shimomura, } \\
2006 \text { ) }\end{array}$ & 73 & shell sand & $\begin{array}{l}\text { Larsen \& } \\
\text { Shimomura, } \\
2006\end{array}$ \\
\hline $\begin{array}{l}\text { Hoplopolemius } \\
\text { triangulatus } \\
\text { (Richardson, 1902) }\end{array}$ & - & - & $\begin{array}{l}\text { Richardson, } \\
1902\end{array}$ \\
\hline $\begin{array}{l}\text { Julmarichardia } \\
\text { alinati Guţu, } 1989\end{array}$ & $6-450$ & - & Guţu, $1989 b$ \\
\hline $\begin{array}{l}\text { Julmarichardia } \\
\text { bajau Bamber \& } \\
\text { Sheader, } 2005\end{array}$ & $23-35$ & $\begin{array}{l}2 \% \text { gravel, } 75-78 \% \\
\text { sand, } 9-12 \% \text { silt, } 10- \\
11 \% \text { clay }\end{array}$ & $\begin{array}{l}\text { Bamber \& } \\
\text { Sheader, } 2005\end{array}$ \\
\hline $\begin{array}{l}\text { Julmarichardia } \\
\text { deltoides (Barnard, } \\
\text { 1914) }\end{array}$ & 90 & - & Barnard, 1914 \\
\hline $\begin{array}{l}\text { Julmarichardia } \\
\text { dollfusi (Guțu, 1989) }\end{array}$ & - & - & Guţu, 1989a \\
\hline $\begin{array}{l}\text { Julmarichardia } \\
\text { gutui Ritger \& } \\
\text { Heard, } 2007\end{array}$ & $78-83$ & - & $\begin{array}{l}\text { Ritger \& } \\
\text { Heard, } 2007\end{array}$ \\
\hline $\begin{array}{l}\text { Julmarichardia } \\
\text { thomassini Guţu, } \\
1989\end{array}$ & 250 & - & Guţu, $1989 b$ \\
\hline $\begin{array}{l}\text { Muvi schmallenbergi } \\
\text { sp. Nov. }\end{array}$ & 49.6 & - & \\
\hline $\begin{array}{l}\text { Trichapseudes } \\
\text { tridens Barnard, } \\
1920\end{array}$ & $31-155$ & - & Barnard, 1920 \\
\hline $\begin{array}{l}\text { Vestigiramus } \\
\text { antillensis Guţu, } \\
2009\end{array}$ & $1-2$ & $\begin{array}{l}\text { dead corals and } \\
\text { seagrass beds }\end{array}$ & Guţu, 2009 \\
\hline $\begin{array}{l}\text { Vestigiramus } \\
\text { codreanui (Guţu, } \\
\text { 1996) }\end{array}$ & 29 & $\begin{array}{l}\text { limestone concretions } \\
\text { and algae }\end{array}$ & Guţu, 1996 \\
\hline $\begin{array}{l}\text { Vestigiramus sp. } \\
\text { Araujo-Silva \& } \\
\text { Larsen, } 2012\end{array}$ & 71.6 & $\begin{array}{l}\text { sandy bottom associated } \\
\text { with sponge and algae }\end{array}$ & $\begin{array}{l}\text { Araujo-Silva \& } \\
\text { Larsen, } 2012\end{array}$ \\
\hline
\end{tabular}


Zaraza linda Guţu, 2006

dead corals covered

Guţu, $2006 b$

1 with algae 